DOI https://doi.org/10.18551/rjoas.2017-10.08

\title{
ECONOMETRIC FORECAST OF AGRIBUSINESS ACTIVITY IN CONTEXT OF FOREIGN DIRECT INVESTMENTS' ATTRACTION
}

\author{
Lytvyn Rostyslav, Research Assistant \\ Lviv National University of Veterinary Medicine and Biotechnologies \\ named after S.Z. Gzhytskyj, Lviv, Ukraine \\ E-mail: lytvynr@ukr.net
}

\begin{abstract}
The main task of economic processes projection in agricultural enterprises is more relevant and vital in recent years with application of applied econometric methods and tools. In represented research paper, these methods are used to forecast primarily economic indicators of LLC «Agrol» and its activity where foreign direct investments (FDI) were attracted from Poland. The linear trend model, the parabolic trend model and the exponential trend model were elaborated from the period from 2000 to 2009 in this scientific study using applied statistical tools STATGRAFICS and EXCEL spreadsheets. And with assistance of these models forecast for key economic indicators on the basis of data of essential indicators of LLC «Agrol» that is located in village of Zhornyska, Yavoriv district, Lviv region, around 55 kilometres away from the border with Poland 2010 and 2011 was made. All models with probability $p=0,95$ are adequate experimental data for researched 2000-2009 years, that allow to make the forecast of the main economic indicators of the researched enterprise in terms of FDI attraction in the region by these models for 2010 and 2011 years. Moreover, it should be noticed, because of small amount of input data, analysis of regression equations coefficients have more qualitative rather than quantitative influence upon resulting variable.
\end{abstract}

\section{KEY WORDS}

Agriculture, foreign direct investment, forecast, linear trend model, parabolic trend model, exponential trend model.

Accordingly to statistical data of agricultural enterprises of Lviv region of Ukraine that are located in cross border locality with Poland provided by Bureau van Dijk Ruslana database for researched 2000-2009 years, presented in tables (1) in this applied study calculate main dynamics and trend models and calculate predicted values and their estimates for forthcoming two years with application of the applied statistical tools STATGRAFICS and EXCEL spreadsheets.

To urgent issues of FDI attraction processes in agriculture of the economy have dedicated one's researches many prominent scientists, among them: R. Ramamurti, N. Hashai [1], J. Jones, C. Wren [2], R. Lytvyn [3] and others. In this represented research paper one's attention is paid to study of Ukraine's agricultural enterprises primary economic indicators projection, where FDI were inflowed and another developing economies in context of globalization with assistance of some applied econometric methods, that are displayed in scientific works of: V. Yeleyko, O. Yeleyko, I. Kopych, R. Bodnar, M. Demchyshyn, O. Synytskyy, A. Chemerys [4-7], G. Cerulli [8], H. Erken, M. Kleijn [9], O. Bjerkholt, A. DupontKieffer [10], P. Wang [11] and C.F. Lee, J.C. Lee [12].

Input data of the models:

Table 1 - Dynamics of LLC «Agrol» primarily activity indicators

\begin{tabular}{|c|c|c|c|c|c|}
\hline Year & $\begin{array}{c}\mathrm{y}_{11} \\
\text { mIn. UAH. }\end{array}$ & $\begin{array}{c}\mathrm{y}_{12} \\
\text { mln. UAH }\end{array}$ & $\begin{array}{c}\mathrm{y}_{13} \\
\text { mln. UAH }\end{array}$ & $\begin{array}{c}\mathrm{y}_{14} \\
\text { mln. UAH }\end{array}$ & $\begin{array}{c}\mathrm{y}_{15} \\
\text { Persons }\end{array}$ \\
\hline 1 & 2 & 3 & 4 & 5 & 6 \\
\hline 2001 & 0,225 & 3,209 & 0,346 & 1,985 & 10 \\
\hline 2002 & 0,854 & 13,649 & 0,984 & 3,469 & 12 \\
\hline 2003 & 1,006 & 19,849 & 1,222 & 3,639 & 34 \\
\hline
\end{tabular}




\begin{tabular}{|c|c|c|c|c|c|}
\hline 1 & 2 & 3 & 4 & 5 & 6 \\
\hline 2004 & $-0,071$ & 0,750 & 0,171 & 3,354 & 15 \\
\hline 2005 & 0,354 & 3,118 & 0,577 & 3,736 & 19 \\
\hline 2006 & 0,364 & 3,207 & 0,545 & 5,619 & 19 \\
\hline 2007 & 1,374 & 9,286 & 1,628 & 8,901 & 20 \\
\hline 2008 & 9,106 & 23,725 & 9,483 & 18,230 & 14 \\
\hline 2009 & 5,391 & 29,247 & 6,075 & 24,614 & 31 \\
\hline
\end{tabular}

Source: https://ruslana.bvdep.com/

Notes: $y_{11}-$ net profit of LLC «Agrol», mln. UAH; $y_{12}-$ cost of sales revenue (turnover) of LLC «Agrol», mln. UAH; $y_{13}-$ cash flow of LLC «Agrol», mln. UAH; $y_{14}$ - assets cost of LLC «Agrol», mln. UAH; $y_{15}-$ quantity of employees at LLC «Agrol», persons.

Thus linear $\left(\tilde{\mathrm{y}}^{\text {lin }}\right)$, parabolic $\left(\tilde{\mathrm{y}}^{\mathrm{par}}\right)$ and exponential $\left(\tilde{\mathrm{y}}^{\mathrm{exp}}\right)$ trend models will look like:

$$
\begin{aligned}
& \tilde{y}_{11}^{\operatorname{lin}}=-1,78797+0,77415 \cdot t \\
& \tilde{y}_{11}^{\text {par }}=2,05038-1,3195 \cdot t+0,20936 \cdot t^{2} \\
& \tilde{y}_{11}^{\exp }=\exp \{-2,0749+0,36773 \cdot t\} \\
& \tilde{y}_{12}^{\operatorname{lin}}=2,13964+1,92852 \cdot t \\
& \tilde{y}_{12}^{\text {par }}=18,165-6,81258 \cdot \mathrm{t}+0,87411 \cdot \mathrm{t}^{2} \\
& \tilde{y}_{12}^{\exp }=\exp \{1,08108+0,17386 \cdot \mathrm{t}\} \\
& \tilde{y}_{13}^{\operatorname{lin}}=-1,79647+0,82665 \cdot \mathrm{t} \\
& \tilde{y}_{13}^{\text {par }}=2,30164-1,40869 \cdot \mathrm{t}+0,22353 \cdot \mathrm{t}^{2} \\
& \tilde{y}_{13}^{\exp }=\exp \{-1,58363+0,33320 \cdot \mathrm{t}\} \\
& \tilde{y}_{14}^{\text {lin }}=-4,12711+2,4598 \cdot \mathrm{t} \\
& \tilde{y}_{14}^{\text {par }}=7,16424-3,69912 \cdot \mathrm{t}+0,61589 \cdot \mathrm{t}^{2} \\
& \tilde{y}_{14}^{\exp }=\exp \{0,30590+0,28922 \cdot \mathrm{t}\} \\
& \tilde{y}_{15}^{\text {lin }}=13,8333+1,1 \cdot \mathrm{t} \\
& \tilde{y}_{15}^{\text {par }}=12,6429+1,74935 \cdot \mathrm{t}-0,06493 \cdot \mathrm{t}^{2} \\
& \tilde{y}_{15}^{\exp }=\exp \{2,53968+0,06939 \cdot \mathrm{t}\}
\end{aligned}
$$

\begin{tabular}{|c|c|c|c|c|c|}
\hline \multirow{2}{*}{ Indicator } & \multicolumn{2}{|c|}{ Indicator forecast } & \multirow{2}{*}{$\mathrm{ME}$} & \multirow{2}{*}{ MSE } & \multirow{2}{*}{ MAE } \\
\hline & 2010 & 2011 & & & \\
\hline 1 & 2 & 3 & 4 & 5 & 6 \\
\hline \multicolumn{6}{|c|}{ mln. UAH } \\
\hline$\tilde{y}_{11}^{\operatorname{lin}}$ & 5,953 & 6,728 & 0 & 4,5472 & 1,7148 \\
\hline$\tilde{y}_{11}^{\text {for }}$ & 9,792 & 12,869 & 0 & 3,0471 & 1,2994 \\
\hline$\tilde{y}_{11}^{\exp }$ & 4,965 & 7,172 & 0,8869 & 5,6557 & 1,3227 \\
\hline \multicolumn{6}{|c|}{ mln. UAH } \\
\hline$\tilde{y}_{12}^{\operatorname{lin}}$ & 21,425 & 23,353 & 0 & 71,4555 & 7,8853 \\
\hline$\tilde{y}_{12}^{\text {for }}$ & 37,450 & 48,994 & 0 & 45,3075 & 5,6839 \\
\hline$\tilde{y}_{12}^{\exp }$ & 16,771 & 19,956 & 4,0210 & 83,4522 & 7,3988 \\
\hline \multicolumn{6}{|c|}{ mln. UAH } \\
\hline$\tilde{y}_{13}^{\operatorname{lin}}$ & 6,470 & 7,297 & 0 & 4,7309 & 1,7954 \\
\hline$\tilde{y}_{13}^{\text {for }}$ & 10,568 & 13,854 & 0 & 3,0209 & 1,3078 \\
\hline$\tilde{\mathrm{y}}_{13}^{\exp }$ & 5,745 & 8,017 & 0,8029 & 5,4556 & 1,3746 \\
\hline \multicolumn{6}{|c|}{ mln. UAH } \\
\hline$\tilde{y}_{14}^{\operatorname{lin}}$ & 20,471 & 22,931 & 0 & 15,4835 & 3,5549 \\
\hline$\tilde{y}_{14}^{\text {for }}$ & 31,762 & 40,997 & 0 & 2,5022 & 1,4437 \\
\hline
\end{tabular}

Where: $\tilde{y}_{i}(i=11,12, \ldots, 15)$ - regulatory or averaged values of the researched indicators; $\mathrm{t}$ - time.

Relevant predicted values and their estimates based on trends (1) - (15) were calculated, that are displayed in table (2).

It is necessary to notice that the closer the values of ME, MSE and MAE to zero, the better will be calculated forecasts value of the appropriate indicators.

Table 2 - Forecasting values and estimation indicators of LLC «Agrol» 


\begin{tabular}{|c|c|c|c|c|c|}
\hline 1 & 2 & 3 & 4 & 5 & 6 \\
\hline$\tilde{y}_{14}^{\exp }$ & 24,486 & 32,699 & 0,6605 & 8,0253 & 2,0953 \\
\hline \multicolumn{7}{|c|}{ Persons } \\
\hline$\tilde{y}_{15}^{\operatorname{lin}}$ & 24,833 & 25,933 & 0 & 51,9333 & 5,3630 \\
\hline$\tilde{y}_{15}^{\text {for }}$ & 23,643 & 24,029 & 0 & 51,7890 & 5,4592 \\
\hline$\tilde{y}_{15}^{\exp }$ & 25,370 & 27,192 & 1,1116 & 53,4749 & 4,8416 \\
\hline
\end{tabular}

Notes: ME - mean value of the error; MSE - mean square value of the error; MAE - mean absolute value of the error.

Net profit forecast of LLC «Agrol» with the least error receive on the basis of parabolic trend model (3.52):

$$
\tilde{y}_{11,2010}^{\text {forecast }}=9,792 \mathrm{mln} . \mathrm{UAH} \mathrm{i} \tilde{y}_{11,2011}^{\text {forecast }}=12,869 \mathrm{mln} . \mathrm{UAH}
$$

Cost of sales revenue (turnover) forecast of LLC «Agrol» with the least error receive with the assistance of parabolic trend model (3.55):

$$
\tilde{y}_{12,2010}^{\text {forecast }}=37,450 \mathrm{mln} \text {. UAH and } \tilde{y}_{12,2011}^{\text {forecast }}=48,994 \mathrm{mln} . \mathrm{UAH}
$$

Cash flow cost forecast of LLC «Agrol» with the least error receive on the basis of parabolic trend model (3.58):

$$
\tilde{y}_{13,2010}^{\text {forecast }}=10,568 \mathrm{mln} \text {. UAH and } \tilde{y}_{13,2011}^{\text {forecast }}=13,854 \mathrm{mln} . \mathrm{UAH}
$$

Assets cost forecast of LLC «Agrol» with the least error receive with the assistance of parabolic trend model (3.61):

$$
\tilde{y}_{14,2010}^{\text {forecast }}=31,762 \mathrm{mln} . \mathrm{UAH} \text { and } \tilde{y}_{14,2011}^{\text {forecast }}=40,997 \mathrm{mln} . \mathrm{UAH}
$$

Quantity of employees forecast of LLC «Agrol» with the least error receive on the basis of parabolic trend model (3.64):

$$
\tilde{y}_{15,2010}^{\text {forecast }}=23,643 \text { persons and } \tilde{y}_{15,2011}^{\text {forecast }}=24,029 \text { persons, }
$$

as well as on the basis of linear trend model (3.63):

$$
\tilde{y}_{15,2010}^{\text {forecast }}=24,833 \text { persons and } \tilde{y}_{15,2011}^{\text {forecast }}=25,933 \text { persons }
$$

Linear paired and multiple regression equations dependence of net profit of LLC «Agrol» $\left(\mathrm{y}_{11}\right)$ on influence of the studied variables indicators based on data in table (1) were elaborated:

$$
\begin{gathered}
\tilde{y}_{11}=-0,64134+0,23121 \cdot y_{12}, \\
R^{2}=0,602297 ; F=10,6011 \\
\tilde{y}_{11}=-0,15670+0,95836 \cdot y_{13} ; \\
R^{2}=0,998444 ; F=4491,68 ; \\
\tilde{y}_{11}=-0,65676+0,33524 \cdot y_{14}, \\
R^{2}=0,734376 ; F=19,3530 \\
\tilde{y}_{11}=-0,06308+1,02200 \cdot y_{13}-0,02965 \cdot y_{14} ; \\
R^{2}=0,999787 ; F=14093,6 \\
\tilde{y}_{11}=-0,04596-0,00434 \cdot y_{12}+1,02743 \cdot y_{13}-0,02704 \cdot y_{14} ; \\
R^{2}=0,999857 ; F=11637,8
\end{gathered}
$$


Regression models $(17)-(20)$, have good credibility, it is a sign of the determination coefficients $R^{2}$, its value is greater than 0,7 and $F-$ criteria that is more greater than $F_{\text {table }}$, but equation (16) has an average probability or credibility, as its value of the multiple determination coefficients is more greater than 0,6 and less than 0,7 .

Analysis of the paired regression equations (16) - (18) indicates positive influence upon net profit of LLC "Agrol» $\mathrm{y}_{11}$ such indicator variables as cash flow cost $\mathrm{y}_{13}$ $\left(B_{13}=0,95836\right)$, assets cost of LLC «Agrol» $y_{14}\left(B_{14}=0,33524\right)$ and cost of sales revenue (turnover) of LLC «Agrol» $\mathrm{y}_{12}\left(\mathrm{~B}_{12}=0,23121\right)$.

Analysis of the multiply regression equation (19) indicates that while increase of cash flow cost of LLC «Agrol» at $1 \mathrm{mln}$. UAH and some constant or average - assets cost value of LLC «Agrol» $y_{14}$ it is expected that net profit of LLC «Agrol» will average increase at 1,022 $\mathrm{mln}$. UAH, at the same time assets cost of LLC «Agrol» $\mathrm{y}_{14}$ will increase at1 mln. UAH abide by constant or average cash flow cost value of LLC «Agrol» $y_{13}$ it is expected that net profit of LLC «Agrol» $y_{11}$ will average decrease at 0,02965 mln. UAH.

Regression coefficients' values of the multiply regression model (20) argue some positive influence on net profit of LLC «Agrol» $\mathrm{y}_{11}$ cash flow cost of LLC «Agrol» $\mathrm{y}_{13}$ $\left(B_{13}=1,02743\right)$ and negative impact - assets cost of LLC «Agrol» $y_{14}\left(B_{14}=-0,02704\right)$ and cost of sales revenue (turnover) of LLC «Agrol» $\mathrm{y}_{12}\left(\mathrm{~B}_{12}=-0,00434\right)$.

Separately, one's should point out that analysis of influence of factor variables on resulting multi variable regression equation (20) has a qualitative, rather than quantitative character.

\section{CONCLUSION}

In this research study linear, parabolic, and exponential trend models of agricultural enterprise LLC «Agrol» of Lviv region, Ukraine primary economic indicators were presented. All the models with probability $p=0,95$ are adequate experimental data for $2000-2009$, that enable to make the projection of the main economic indicators of the researched agribusiness where FDI were inflowed by these models for 2010 and 2011. However, it should be noticed, because of small amount of input data analysis of regression equations coefficients have more qualitative than quantitative influence upon resulting variable.

\section{REFERENCES}

1. Ramamurti R., Hashai N. The future of foreign direct investment and the multinational enterprise - Emerald Group Publishing. - 2011. - 452 p.

2. Jones J. Foreign direct investment and the regional economy. - Ashgate. $-2006 .-248$ p.

3. Lytvyn R. Econometric forecast of agricultural sector investing in Lvov region // Russian Journal of Agricultural and Socio-Economic Sciences. - 2014. - Vol.7(31). - P. 3-7.

4. Yeleyko V.I. Ekonometriya.: Navchal'nyj posibnyk. - Lviv: 2007. - 349 s.

5. Yeleyko V.I., Yeleyko O.I., Synytskyy O.S., Chemerys A.O. Ekonometrychni metody prognozuvannya. - K.: Vydavnytstvo UADU, 1998. - $115 \mathrm{~s}$.

6. Yeleyko V.I. Ekonomiko-statystychni metody modelyuvannya I prognozuvannya. - K.: 1988. - $88 \mathrm{~s}$.

7. Yeleyko V.I., Osnovy ekonometriyi. - Lviv.: TzOV «MARKA Ltd», 1995. - Ch. 1. - $192 \mathrm{~s}$.

8. Cerulli G. Econometric evaluation of socio economic programs. - Springer.-2015.-308 p.

9. Erken $\mathrm{H}$. Location factors of international R\&D activities: an econometric approach // Economics of innovation and new technology. . - 2010. - Vol. 19(3). - P.203 - 232.

10. Bjerkholt O. Problems and methods of econometrics. - Routledge. $-2009 .-149 \mathrm{p}$.

11. Wang P. Financial econometrics econometrics. - Routledge. $-2009 .-320$ p.

12. Lee C.F. Handbook of financial econometrics and statistics. - Springer.-2015.-2903 p.

(C) 2017 by the authors. Licensee RJOAS, Orel, Russia. This article is an open access article distributed under the terms and conditions of the Creative Commons Attribution (CC BY) license: http://creativecommons.org/licenses/by/4.0/ 